\title{
Local wisdom of indigenous society in managing their customary land: a comparative study on tribes in Indonesia
}

\author{
Maria \\ Faculty of Law, Private Law Department, Universitas Sumatera Utara, Indonesia
}

\begin{abstract}
The knowledge of indigenous people in Indonesia has developed for years in line with the development of human civilization. The development produces traditional knowledge and rules resulting from the adaptation process to its environment. The recent emergence of environmental crises has created a new awareness that this crisis can be resolved by returning to the local wisdom of indigenous peoples. The discourse on local wisdom has surfaced and is recognized as an important part of future development programs, including legal development. Local wisdom or environmental wisdom can be defined as the cultural knowledge possessed by a particular society that includes a number of cultural knowledge concerning models of sustainable use and management of natural resources. The legal relationship between the community and the land creates a right that gives the community a legal group, the right to use the land for the benefit of the society. In local communities, traditional wisdom manifests in the form of a set of rules, knowledge and skills as well as values and ethics that govern the social order of the communities that continue to live and evolve from generation to generation. This local wisdom is not only contained in the customary values and norms but also in the activities of indigenous people members in managing their lands.
\end{abstract}

\section{Introduction}

The knowledge of indigenous people in Indonesia has been developing for a long time in line with the development of human civilization. This development has emerged various new knowledge and traditional values as a result of the adaptation to their environment. In accordance with the basic human needs, one of the developing traditional knowledge is the knowledge about land use either for residential purposes or for commercial purposes [1].

In order to fulfill their needs, man will use everything provided in their surrounding environment. Man tends to lead themselves to Dutch Disease Syndrome which is human overexploitation of the natural resources for his own benefit without paying attention to the sustainability of those natural resources [2]. Therefore, man attempts to adapt in order to gain a balance and sustainability between the society and the environment, one of which is through establishing social control systems in the form of norms and customary law derived from that society. The current environmental crisis has raised a new awareness that such crisis can be resolved by going back to the local wisdom of the indigenous society. The idea of local wisdom has emerged to the surface and has been approved as an important part in 
the future development program including legal development [3]. Through this way, not only could the existence of indigenous people with all their wealth and local wisdom be saved, but also the ecological crisis caused mainly by the wrong perspective and behavior of the modern society [4].

The purpose of this article is to describe the local wisdom of indigenous peoples in Indonesia in managing their ulayat land. This discussion is then divided into several parts : (1) Understanding the meaning of local wisdom; (2) what is ulayat land; (3) local wisdom of indigenous peoples in Indonesia; (4) the relationship of UUPA and tanah ulayat.

\section{What local wisdom is}

Local wisdom can be simply defined as the cultural knowledge owned by a certain society which includes an amount of cultural knowledge concerning the models of sustainable natural resource utilization and management [5]. According to Law Number 32 of 2009, local wisdom is the noble values prevailing in the society's life to protect and manage sustainable living environment [6]. The Law also formalizes the government responsibility to acknowledge, respect, and protect the rights of the indigenous society, the traditional society, and the local wisdom over the coastal areas and small islands that have been used from generation to generation.

In addition, I Nyoman Nurjaya describes local wisdom in accordance with the Indonesian people mindset as follows:

"Fundamentally, it originates from the values and religious systems that the community adheres to. Religious teaching and belief of the local community en soul, give color, and affect the environmental image in the form of attitude and behavior towards the environment. This implies that it provides guidance to humans to act in a harmony with the rhythm of the universe that it will create a balanced relationship between the human and the environment [7]."

Local wisdom contains local institution or system of norms embodying values, principle, structure, institution, mechanism and religion that grow, develop and are adhered to within the community. It serves as the instrument to maintain the order of interaction among the community (social order), the order of relationship with The Creator and spirits that are believed to have supernatural power (spiritual order), or the order of community's behavior towards their environment (ecological order) [7].

In relation to the utilization and management of natural resources and environmental sustainability, this indigenous people with their indigenous knowledge, their ability to uphold the customary law, their spiritual ability, and religion turn out to be wiser compared to other societies. The indigenous knowledge known as local wisdom grows and develops in the society as knowledge passed down from generation to generation as a part of their adaptation towards the environment.

\section{Ulayat (communal) land}

Van Vollenoven initially introduced the term "Beschikkingsrecht" for naming the ulayat rights; however, after the Indonesian independence, the communal land managed by this indigenous society was called ulayat land. The land ruled by indigenous society, also called customary land/ulayat land/tanah hak pertuanan, is a land under a legitimate reign of indigenous society [8]. Although the term of ulayat land differs for every region in Indonesia [9], there is a uniformity to call it ulayat land and the right over the land is called ulayat right. 
The word ulayat itself means the environment of mastership and ownership according to indigenous literature [10]. The right of the indigenous society to manage ulayat land is called ulayat right. This right exists if there is a fellowship of the law "claims to have within a certain area the exclusive right to avail itself on land" [11]. Indonesia also recognizes the existence of ulayat right [12] proven bythe existence of various rules concerning ulayat right. Unfortunately, the implementation of this rule becomes unclear and, in fact, causes problems to the indigenous society [13]. There are many court cases where a group of people act on behalf of indigenous society to claim a freehold land to be the ulayat right of that indigenous society. The recognition of the existence of indigenous society in Indonesia [14] gives authority to organize their fellowship based on their customary law system as long as it is in accordance with the constitution of the Republic of Indonesia. For indigenous society, - considering the fact that Indonesia is an agrarian country - land has a very important function. Land plays an important role because of [15] (1) the nature of the land, land is the only natural resource that will stay in its original state under any circumstances, even becomes more useful. (2) the land fact, the reality of land is the residence of the fellowship of the law and all its members and gives a living for its owner, (3) the magic-religious aspect of land, as land is a unity which serves as a place for the burial of the land's owner and the ancestors of the fellowship of the law from the previous generations.

The religio-magic close relationship between indigenous society and the land makes the fellowship obtain the right to rule the land, use the land, gather the crop from plants and trees growing on the land, and hunt the animals living on that land [16]. Land is a place where indigenous society lives and a place that gives a living for them [17]. Hence, it can be said that "The ownership and use of land, especially among traditional producers in most developing countries, is not just a source of livelihood, but also a symbol of identity, dignity, solidarity, and peace" [18].

The land ruled by indigenous society, also known as customary land or ulayat land ortanah hak pertuanan, is land under the legitimate reign of indigenous society [8]. According to Boedi Harsono, ulayat right is the name given by the law and the jurists indicating a legal relationship between a certain indigenous society and a certain region which is the "lebensraum" [19] for its members forever [13].

The concept of customary law referring to ipso facto, occupation, placement, mastership, and cultivation is the beginning of the emergence of the right [20]. The relationship between a man and his land is highly determined by the intensity of defacto, man's utilization or cultivation over the land [21].

Ulayat land mentioned here is not always the land physically, it is also the forest, the pond, the river, the lake, and even the sea [22]. The utilization of the ulayat land also differs in each region depending on the creativity of the society in cultivating the land. For instance, in Juhar, Karo District, North Sumatra, the ulayat land is a pond that will be harvested once a year and enjoyed by all the members. These variations in indigenous land use arise in part from contextual and historical factors, as emphasized by many small-scale case studies of indigenous land use [23].

Iman Sudiyat named ulayat right as ancient right, which is the right owned by a certain clan/gans/stam, villages union (doper bond), or usually only one village to rule the whole land in that region [24]. Ulayat right is the highest mastership right in an indigenous society over the land that belongs to all its members [25].

Regarding the relationship between the indigenous society and their ulayat land, Ter Haar stated that this society has the right over their land and is allowed to apply that right inside and outside the land [10]. Applying it outside means the society is responsible for sustaining ulayat land and has the right to refuse or accept outsiders who want to enjoy their land based on the members' agreement. For instance, in indigenous society of Karo, 
an outsider who wants to enter and cultivate the ulayat land has tobe approved by the runggun [26] led by a chieftain. For Indonesia, such settlement earns support from cultural roots living and respected in the social interaction rules [27]. Meanwhile, applying it inside means the indigenous society organizes how the members carry out their right accordingly by limiting the allotment of personal rights and demand and withdrawing a certain part of the land from the right to enjoy it individually for the sake of public interest.

The legal relationship between society and their land creates a right that makes the society a legal group who can use the land for the society's benefit [13].

\section{Local wisdom of indigenous society in Indonesia in managing ulayat land}

Known as an archipelago, each tribe spread throughout Indonesia has their own local wisdom in managing their ulayat land. There are so many tribes with their own local wisdom inhabiting Indonesia. Nevertheless, we can pull out a connecting line as the common trait from the uniqueness of each tribe in managing their ulayat land. In local society, traditional wisdom manifests itself in a set of rules, knowledge, skills, and system of values and etiquette controlling social order in the community that keeps living and developing from generation to generation. This local wisdom is not only found in the customary norms and values but also in the activities of indigenous society in managing their ulayat land.

The local wisdom of the Malay indigenous societyis reflected in their proverb:

Kalau binasa hutan yang lebat

Rusak lembaga hilanglah adat [28]

The proverb above clearly shows a close relationship between the local society and their environment that they draw an analogy between deforestation and custom breakdown. It also shows a strong bond between Malay people and their environment.

For the Karonese indigenous society in Karo District, the concept of managing ulayat land is carried out with a ban on tree-cutting for commercial interest. This is controlled by all the members of the indigenous society in that region.

In the society of Nagari Kambang, Pesisir Selatan District, the society of Guguk Malalo, Tanah Datar District, and the society of Simanau, Solok District in West Sumatra, the concept of managing the forest is a communal conception based on the ulayat mastership over natural resources. This conception of ulayat is holistic, either for the land, forest, water, lake, orthe sea. This is in line with Minangkabau proverb:

Ka rimbo babungo kayu (Ke rimba berbunga kayu)

Ka ladang babungo ampiang (Ke ladang berbunga emping)

Ka sungai babungo pasie (Ke sungai berbunga pasir)

Ka lauik babungo karang (Ke laut berbunga karang) [29]

Article 5 of Regional Regulation Number 13 of 1983 formalizes the function and role of KAN (Kerapatan Adat Nagari = Council onTraditional Law and Customs) in preserving, sustaining and utilizing the natural wealth of district, ulayat, tribe and clan for the sake of public welfare that can be achieved by:

1. Conducting inventory of district's wealth and ulayatof tribe and clan.

2. Legalizing the wealth of district, ulayat, tribe, and clan done by $K A N$.

3. Utilizing the wealth of district, ulayat, tribe, and clan by society/district's member should be approved by $K A N$ in a form of $K A N$ 's legalization:

a. The use of district's wealth should gain $K A N$ 's approval in advance.

b. The use of ulayat of tribe and clan should gain the chieftain's approval in advance.

4. Utilizing the wealth of district, ulayat, tribe, and clan by government for public and social interests should be approved by $K A N$ in a form of $K A N$ 's legalization: 
a. The use of district's wealth should gain $K A N$ 's approval in advance.

b. The use of ulayat of tribe and clans hould gain the chieftain's approval in advance.

5. Utilizing the wealth of district, ulayat, tribe, and clan by government for public and social interests is carried out under the members' agreement based on the principle of "Adat diisi Limbago dituang/siliah jariah"(the decision must be based on a consensus among the members of the society)

6. Utilizing the wealth of district, ulayat, tribe, and clan by investor/private, BUMN (State-Owned Enterprises), BUMD (Regional-Owned Enterprises), Cooperative, and Institution should be approved by $K A N$ in a form of $K A N$ 's legalization:

a. The use of district's wealth should gain $K A N$ 's approval in advance.

b. The use of ulayat of tribe and clan should gain the chieftain's approval in advance.

7. Utilizing the wealth of district, ulayat, tribe, and clan by investor/private, BUMN (State-Owned Enterprises), BUMD (Regional-Owned Enterprises), Cooperative, and Institution is carried out under the members' agreement based on the principle of "Adat diisi Limbago dituang / siliah jariah" (the decision must be based on a consensus among the members of the society) in the form of:
a. Inclusion of share
b. Inclusion of Rights to Cultivate
c. Inclusion of Rights to Build
d. Inclusion of Rights to Use
e. Inclusion of Rights to Lease
f. Inclusion of Rights to Manage
g. Inclusion in other forms [25]

The principle of "Adat diisi Limbago dituang / siliah jariah" (the decision must be based on a consensus among the members of the society) shows the local wisdom of Minangkabau society in preserving natural resources (ulayat) either in the forest, the land/field, the river, or the sea.

Unlike European people who lay the foundation of their legal culture in writing (literally), Indonesian people develop oral tradition culture [30]. A customary law mostly consists of unwritten laws that are understandable to the members. Hence, the way or method used to socialize the values, principles, and norms of the law is also carried out orally by using such instruments as: folklore, myth, chronicle, poem, song and proverb. The bad people are always described as being cynical and opportunistic but they will eventually be defeated by the good people. Meanwhile, the good people are described as being humble, polite and respectful that all their good deeds are always blessed by the Almighty God.

The indigenous society of Maluku living in small islands or coastal areas has a system called "Sasi" which is a prohibition against harvesting or taking away a certain natural resource (either from sea or land) for a certain time. Sasi is an attempt to maintain the quality and the population of the natural resources. The practice of Sasi covers both the natural resources in the sea and on land. On land, Sasi is applied for plants and fruits where at certain time the plants are not allowed to be harvested in order to get more gains that can fulfill the needs of the indigenous society. Sasi starts with a traditional ceremony called "Tutup Sasi" and ends with a ceremony called "Buka Sasi". This shows that indigenous society and their environment have united that they value the nature as they value themselves [31].

Furthermore, the government also empowers the indigenous society in doing nature conservation. For instance, in managing Batang Gadis National Park, the indigenous society of Mandailing Natal has a local wisdom as follows: (1) Harangan Rarangan or a restricted forest, is a forest owned by a village that is not allowed to be used as farmland and the trees cannot be cut down neither for domestic nor commercial purposes. (2) Lubuk 
Larangan is the belief in spirits, for instance the water and the fish in a river that are forbidden to take except for social and religious purposes. Taking them will reputedly lead to sanction and sickness. (3) Bahasa Daun means that the indigenous society of Mandailing Natal has the philosophy of interacting with the nature [32].

Traditionally, the community of Angkola and Mandailing in Tapanuli Selatan understand several basic concepts concerning spatial distribution and region mastership with its natural resources. Three of the concepts are Banua, Huta, and Janjian. Banua means one region, Huta means one settlement, and Janjian means the territorial fellowship of some Banua which is bound by one custom [3].

The legal protection for the rights of indigenous society of Baduy, particularly their ulayat right, is actually listed in the Regional Regulation of Lebak District Number 32 of 2001 on Protection of Ulayat Right of Baduy Society (National Gazette of Lebak District Number 65 Series C of 2001 as Supplement to the National Gazette of Lebak District Number 4) (hereinafter is called Regional Regulation of Ulayat Right of Baduy Society). The enactment of this Regional Regulation is done becausethe Local Government of Lebak District considers Baduy society as a society who has a strong bond with their customary law; therefore, there needs to be a legal protection for ulayat lands of Baduy society. The Regional Regulation of Ulayat Right of Baduy Society is one example of government concerns towards ulayat right of indigenous society where the government does not only recognize their right but also gives them a guaranteed protection.

\section{UUPA (Basic Agrarian Law) protects ulayat land?}

The enactment of UUPA (Basic Agrarian Law) is a fundamental change in land law (agrarian law). It is considered as the important milestone in the history of Agrarian in Indonesia in general and as the renewal of Agrarian Law in particular. This is because the Agrarian Law in Indonesia was previously dualistic in nature. It was rooted in the customary law and the Western Agrarian Law which was the result of the regulation in colonial era [33].

The recognition of customary law or customary rights particularly in the field of land is arranged in Law Number 5 of 1960 on the Basic Regulation of Agrarian Law and the rules underneath. The General Explanation III of Basic Agrarian Law [34] states:

"The Agrarian Law applicable to the land, water and airspace is Adat Law (customary law) as long as it does not contradict the national interest and the interest of the State, which are based on national unity, the Indonesian socialism, other legislations and religious law." The explanation of this article affirms that customary law is made as the foundation of the new law [35].

UUPA, as the law defending indigenous society's interest and the law embodying Indonesianationalism, also formalizes in Article 3 that ulayat right in villages can only be recognized and maintained as long as the society still exists when the UPPA is valid [36].

However, if one uses reverse logic [37], the government or the ruler at that time actually says that the indigenous society does not exist anymore. By using euphemism (substitution of expression for unpleasant word), the words "... as long as the society still exists..." mean the society is no longer existed as long as their existence is not yet proven. If the indigenous society as the element in establishing the State is not existed, then the State denies itself of being an existing state. The implementation is that the State itself is pessimistic towards the existence of the indigenous society.

The regulation of ulayat right means the recognition to guarantee and give legal protection for the rights of indigenous society along with its limitations. This regulation becomes a dilemma faced by ulayat right that it does not give legal protection and 
guarantee of law certainty of ulayat right following its purpose and foundation as a legal norm [8].

UUPA does not clarify the criteria regarding the existence of the ulayat right. Nevertheless, by referring to the fundamental understandings mentioned above, the criteria to determine the existence of ulayat right can be seen in the following conditions:

1. The presence of indigenous society that meets certain criteria, as the subject of the ulayat right;

2. The presence of land/region with certain borders as the Lebensraum and the object of the ulayat right; and

3. The presence of authority of indigenous society to carry out certain acts as explained above [38].

The practice of ulayat right, as long as it has been existing, is done by the indigenous society in accordance with their customary law. The ulayat right of the indigenous society is considered still in existence if: 1) There are still a group of people who feel attached to their customary law as one fellowship of a certain law, recognize, and carry out the laws in their daily lives. 2) There is a certain ulayat land as a living place for the fellowship of the law and the place to get their daily needs, and 3) There is a customary law regarding arrangement, mastership, and utilization of ulayat land that the fellowship abides by.

A research and determination for the existence of ulayat right are conducted by the Local Government involving the experts in customary law, the indigenous society in that region, Non-Governmental Organization, and the institutes managing natural resources. The ulayat land that still exists will be included in the base map of land registration by adding cartographic mark and if possible drawing the borders and including it in the land register. In the cases of land conflict, none of indigenous societies won the 1,400 cases of land dispute in West Sumatera Court. The same casea pplies to Ulayat Right of District where approximately 100 ha of the area has become the property of Ministry of Forestry [39].

The enactment of Regulation of the Minister of Agrarian Affairs Number 9 of 2015 on the Procedures of the Establishment of Communal Right over the Land of Indigenous Society and the Society in a Certain Region (Permen ATR 9/15) should be able to fulfill the needs of indigenous society regarding their rights over natural resources which have not yet been well protected. This makes the relationship between indigenous society and the natural resources become distant. The indigenous society has been forced to detach their bond with land, forest, water and other natural resources they own.

In actual practice, there are still pros and cons among the academicians regarding the enactment of Permen ATR. Some experts state that the regulation needs to be reviewed in terms of its lack of recognition of diversity in the character of the right of the indigenous society over their land and natural resources. Furthermore, the equalization of indigenous and non-indigenous society as the subject of communal right can cause an overlap of right between indigenous and non-indigenous society living in the same place and for a long time.

For ulayat right in particular, during the four decades of UUPA enactment, there is no law that implements such recognition [29]. There is no regulation that firmly recognizes the existence of ulayat right. In its implementation, ulayat right is not well identified that its status is often considered as the same as (included as) State's land. Overlap of ulayat land often happens when giving the Rights to Cultivate for farming and other purposes.

For instance, the land dispute between tribe of Dayak Bentian and HPH/HPHTI (Natural Forest Management Permit/Industrial Forest Plantation Permit) companies started when the forest which used to bea part of the tribe's territory was taken over by the companies [40]. The tribe was troubled by the companies making buildings on their ulayat land and disturbing the river ecosystem. 


\section{Local wisdom in the management of ulayat land: past and present}

Conflicts of the management of natural resources happen because of the overlap of claim on territory. The indigenous society who feel they have the highest right over their territory are often ignored by the government who gives concessions to companies for using customary land or making it as a conservation area. Actually, the participation of indigenous society in preserving ulayat forest in the conservation area is very important since they have lived there from generation to generation long before the conservation area was made and they have had intense interaction with the area. This intense interaction surely enables them to be the reliable guardians of the conservation since they already have their own values or principles of conservation (local wisdom) in their souls. Basically, the ones who can protect environment are those who have conservation awareness.

However, as the time changes, the local wisdom of managing ulayat land does not only collide with regulations but also with the sweet talk from the plantation owners. Many chieftains of the indigenous societies were deceived by the plantation owners to hand their ulayat land for money, resulting in reducing and even losing the ulayat land.

\section{Conclusion}

The recognition of ulayat land under the UUPA is the recognition of the right of indigenous society, on condition that the ulayat right still exists and does notcontradict the higher purposes. This means there is a limitation to the existence of the right which is put on a weak position, even very possibly to be eliminated.

The regulation of rights of indigenous society for natural resources is still general and abstract. It seems like there is still a limitation to the rights of the indigenous society thus legislation initiative only rewrites the rights of indigenous society listed at the higher regulation. Therefore, clear justification and regulation are needed in determining the rights of the indigenous society to eliminate the obscurity of its existence.

As Hooker said, "The basic issue at the root of all Indonesian land system is the relationship between the community and individual interest."

\section{References}

1. N. Kosmaryandi. Kajian penggunaan lahan tradisional Minangkabau berdasarkan kondisi tanahnya (Study of Minangkabau traditional landuse based on its soil condition). Media Konservasi X, 2 (2005)

2. A. Satria. Penguatan kapasitas masyarakat desa dalam akses dan kontrol terhadap sumber daya alam. Seminar and Workshop Toward the 2030 Village, at the Management and Business Master's Program of IPB. (2007)

3. Z.B. Lubis. Menumbuhkan (kembali) kearifan lokal dalam pengelolaan sumberdaya alam di Tapanuli Selatan. Antropologi Indonesia, Indonesian Journal of Social and Cultural Anthropolgy 29, 3 (2005)

4. S. Keraf. Etika Lingkungan (Kompas, Jakarta, 2002)

5. Y.R. Zakaria. Hutan dan Kesejahteraan Masyarakat (Penerbit WALHI, Jakarta, 1994)

6. Law Number 32 of 2009 on Environmental Protection and Management Article 1 Paragraph 30

7. S. Irianto. Hukum yang Bergerak: Tinjauan Antropologi Hukum (Yayasan Pustaka Obor Indonesia, Jakarta, 2009) 
8. D. Samosir. Hukum Adat Indonesia Eksistensi Dalam Dinamika Perkembangan Hukum di Indonesia (Nuansa Aulia, Bandung, 2013)

9. Taneh Kesain (Karo), Ulayat (Minangkabau), Popah (Sakai)

10. S. Soekanto. Kamus Hukum Adat (Penerbit Alumni, Bandung, 1982)

11. Mahadi. Uraian Singkat Tentang Hukum Adat Sejak RR Tahun 1854 (Penerbit Alumni, Bandung, 1991)

12. Basic Agrarian Law, Environmental Management Act, Plantation Law, Water Resources Law, and other laws

13. A.S. Hutagalung, Tebaran Pemikiran Seputar Masalah Hukum Tanah (Lembaga Pemberdayaan Hukum Indonesia, Jakarta, 2005)

14. The recognition on indigenous society is regulated in Article 28 Paragraph I (2) of the 1945 Constitution which reads: The cultural identity and rights of indigenous society are respected in line with the times and civilizations.

15. I.G.A.B. Wiranat. Hukum Adat Indonesia (PT. Citra Aditya Bakti, Bandung, 2005)

16. T. Setiady. Intisari Hukum Adat Indonesia (Dalam Kajian Kepustakaan) (Penerbit Alfabeta, Bandung, 2008)

17. S. Soekanto, S.B. Taneko. Hukum Adat Indonesia (Penerbit Rajawali, Jakarta, 1986)

18. Egemi 2006a, 2006b; El Hadary 2010; Komey 2009 in Yasin Abdalla Eltayeb ElHadary and Franklin Obeng Odoom.Conventions, Changes, andContradictions in Land Governance inAfrica: The Story of Land Grabbing in North Sudan and Ghana, Africa Today, Journal, p. 59.

19. Lebensraum is the right of a nation's living space to ensure its welfare and security. Retrieved June 29, 2017 from http://www.organisasi.org/1970/01/ajaran-lebensraumautarki-dan-pan-region-oleh-karl-haushofer-orang-jerman-pengertian-dan-arti-defenisiilmu-sejarah-dunia.html, Ajaran Lebensraum, Autarki dan Pan-Region oleh Karl Haushofer Orang Jerman-Pengertian dan Arti Defenisi-Ilmu Sejarah Dunia

20. O.K. Saidin, Mencari dan Menjadi Hukum Indonesia, Refleksi Pemikiran Prof. Mahadi (PT. Raja Grafindo Persada, Jakarta, 2016)

21. S. Wignjosoebroto. Perbedaan konsep tentang dasar hak penguasaan tanah antara apa yang dianut dalam tradisi pandangan pribumi dan apa yang dianut dalam hukum positif Eropa. A Paper presented in the Seminar on Agrarian Law in the Commemoration of the 30th Birthday of UUPA (1960-1990), (1990)

22. In Karo Regency, for example, tapin (a fountain) becomes ulayat land managed by indigenous society.

23. C.L. Gray, R.E. Bilsborrow, J.L. Bremner, F. Lu. Indigenous land use in the ecuadorian amazon: a cross-cultural and multilevel analysis. Springer Science + Business Media, LLC 2007, Published online: 19 October 2007, Hum Ecol (2008) 36:97-109, Journal, p. 98

24. I. Sudiyat. Hukum Adat Sketsa Asas (Liberty, Yogyakarta, 1978)

25. H. Panuh. Pengelolaan Tanah Ulayat Nagari Pada Era Desentralisasi Pemerintahan di Sumatera Barat (PT. Raja Grafindo Persada, Jakarta, 2012)

26. Rungguncan be defined as an institutional process of formal deliberation and decision making through consensus by a group of people bound by such kinship as senina, anakberu, and kalimbubu, which forms a unity (sangkep si telu). Herman Slaats and Karen Portier, Traditional Decision-Making and Law (Gadjah Mada University Press, Yogyakarta, 1992) 
27. Maria SW Sumardjono, et al. Mediasi Sengketa Tanah, Jakarta: Kompas, 2008, p. 5.

28. T. Effenddy. Tunjuk Ajar Melayu (Butir-Butir Budaya Melayu Riau) (Adicita Karya, Yogyakarta:, 2004)

29. K. Warman, at al. Nasib Tenurial Adat Atas Kawasan Hutan (Huma dan Qbar, Jakarta Selatan, 2007)

30. D. Rato. Hukum Adat di Indonesia (Laksbang Justitia Surabaya, Surabaya, 2014)

31. Kuwati, dkk. Konservasi Berbasis Kearifan Lokal (Studi Kasus: Sasi di Kabupaten Raja Ampat), Proceedings of Raja Ampat National Seminar WAISAI 12 - 13 August 2014, Universitas Kristen Satya Wacana, (2014)

32. G. Lumbantoruan. Kearifan Lokal Masyarakat Hukum Adat Mandailing Natal dalam Pengelolaan Taman Nasional Batang Gadis Sumatera Utara, Retrieved August 18, 2017 from http://lumbanlaw.blogspot.co.id/2013/01/kearifan-lokal-masyarakat-hukumadat.html

33. Indonesia had been colonized by the Dutch for almost 350 years; consequently, there are still many colonial state regulations still in force today in accordance with Article 1 of the Transitional Constitution of the 1945 Constitution.

34. The new Agrarian Law must correspond to the legal consciousness of the masses, since the Indonesian people are largely subject to customary law, then the new agrarian law will be based also on the provisions of customary law, as the original law, which is completed and adapted to the interests of society in a modern state in relation to the international world and adapted to Indonesian socialism. The customary law in its growth is inseparable from the political influence and colonial society which is capitalist and self-governing society

35. M. Koesnoe. Catatan-catatan Terhadap Hukum Adat Dewasa Ini (Airlangga University Press, Surabaya, 1979)

36. AP. Parlindungan. Hak Pengelolaan Menurut Sistem UUPA (Mandar Maju, Bandung, 1989)

37. Reverse logic is the opposite action to the command "as long as it has existed..." its implication should have no longer been in existence."

38. M.S.W. Sumardjono. Kebijakan Pertanahan Antara Regulasi dan Implementasi (Kompas, Jakarta, 2001)

39. Emil Kleden and the results of the research by Asep Yunan Firdaus Jawahir Thontowi, et al. Aktualisasi masyarakat hukum adat (MHA): Perspektif hukum dan keadilan terkait dengan status MHA dan Hak-hak Konstitusionalnya. Jakarta: Pusat Penelitian dan Pengkajian Perkara, Pengelolaan Teknologi Informasi dan Komunikasi Kepaniteraan dan Sekretariat Jenderal Mahkamah Konstitusi Republik Indonesia, (2012)

40. M.S.W. Sumardjono. Mediasi Sengketa Tanah (Kompas, Jakarta, 2008) 